STUDIES IN ENGLISH LITERATURE

Volume LXXIII 



\title{
A BABBLE OF
}

ANCESTRAL VOICES

Shakespeare,Cervantes, and Theobald

\author{
by \\ HARRIET C. FRAZIER
}

1974

MOUTON

THE HAGUE - PARIS 
(C) Copyright 1974 in The Netherlands

Mouton \& Co. N.V., Publishers, The Hague

No part of this book may be translated or reproduced in any form,

by print, photoprint, microfilm, or any other means, without written permission from the publishers

LIBRARY OF CONGRESS CATALOG CARD NUMBER: 73-83204

Printed in Belgium by NICI, Ghent 
To the Memory of

Joella Owens Brown (1936-1965)

and

Edward Emley (1916-1966) 

Genius, all over the world, stands hand in hand, and one shock of recognition runs the whole circle round.

Herman Melville 
